\title{
Assessment on Motivation Factors of Agripreneurs in Nueva Ecija
}

\author{
Kim Edward S. Santos, Carl Louie R. Nocum, Crisanto D. De Jesus
}

Instructor, College of Management and Business Technology, Atate Campus, Nueva Ecija University of Science and Technology, Nueva Ecija, Philippines

Received: 11 Oct 2021; Received in revised form: 15 Dec 2021; Accepted: 22 Dec 2021; Available online: 31 Dec 2021 (C)2021 The Author(s). Published by Infogain Publication. This is an open access article under the CC BY license (https://creativecommons.org/licenses/by/4.0/).

\begin{abstract}
Stimulating entrepreneurial activity in agriculture, through targeted training in agricultural entrepreneurship, could possibly an answer to the emerging situation. Entrepreneurship shifts the focus from producing more of the same things to producing value-added goods and services through managed agricultural risks.The study described personal and business profile of the respondents. The study assessed the motivation factors of agripreneurs in terms of Job Characteristics, Critical Psychological State and Job Satisfaction. Further, this study determined the relationship between and among the profile of the respondents and motivation factors of agripreneurs. This study used descriptive-correlational design. This study determined the relationships among sociodemographic and business profile of agripreneurs, motivation factors and challenges that were gathered through an online questionnaire.The researcher used purposive quota sampling in selecting the respondents. A quota of 62 agripreneurs in Nueva Ecija was established. Based on the results of the study, agripreneurs in Nueva Ecija are motivated by job characteristics where they understood that their job requires a wide range of skills because it is not simple or repetitive. They believed their job has meaning for them because of its importance and usefulness, which meant a lot to them as agripreneurs. This contributed to how they impact the well-being of their clients. Thus, agripreneurswere satisfied with their jobs when they face personal work challenges. Then, the main motivating factor for agripreneurs was found to be job satisfaction. Future researchers may explore more on the demographic of the agripreneurs. They may include courses of the agripreneurs if these were related to their job, trainings, and seminars attended in relation to agribusiness. Profile of the agripreneurs have positive correlations to motivating factors such critical psychological state and job satisfaction but only limited to age, highest educational attainment, number of years in the agribusiness, and average monthly income. Further, job characteristics as a motivating factor were found no significant relationships with the profile of the agripreneurs.
\end{abstract}

Keywords-Agripreneurs, Motivation Factors, Agribusiness, Agriculture.

\section{INTRODUCTION}

Stimulating entrepreneurial activity in agriculture, through targeted training in agricultural entrepreneurship, could possibly an answer to the emerging situation. Entrepreneurship shifts the focus from producing more of the same things to producing value-added goods and services through managed agricultural risks. In order to encourage the development of opportunities and value creation in this sector, current farmers need to be trained to become more entrepreneurial and to educate future generations to become agricultural entrepreneurs (Santiago \&Roxas, 2015).

In the context of aging farmers and rural-urban youth migration, attention has shifted to agricultural or agribusiness entrepreneurship as a strategy to modernize the agricultural sector (Yusoff, 2017). Bairwa, Lakra, Kushwaha, Meena and Kumar (2014) stated that applying the principles of entrepreneurship to the agricultural sector can provide a host of benefits, ranging from employment 
and income generation to the creation of innovative products and poverty reduction.

Based from the review report of the Philippine Statistics Authority in 2004, Nueva Ecija shared the largest number of farms in Central Luzon and also the biggest among the provinces. Palay was the major temporary crop in Nueva Ecija alongside with tubers, roots and bulbs, corn, sugarcane, and fruit bearing vegetables. It was reported a high proportion of livestock such as goats and hogs and also raising poultry like ducks, chicken,and quails came from this province. In addition to their review, thousand household members in Nueva Ecija were engaged in agricultural activities. While male operators dominated the agricultural operation, females engaged as helpers of their own farms or workers of other farms. In general, based on the report, farmers in Nueva Ecija are actually helpers or workers either on their own farms or from others and none was mentioned if these farmers were engaged into entrepreneurship.

With the scenarios presented, it is important to know how the agripreneurs are doing despite some challenges or problems encountered. There is a shortage of studies in the Philippines that examine motivation factors of these agripreneurs in relation to job satisfaction.

\section{CONCEPTUAL FRAMEWORK}

Using Oldham and Hackman's Job Characteristic Theory, the research employed variables that specifically anchored to the theory and also based on empirical studies. Research on job satisfaction and motivation are ones of the most addressed issues in organizational psychology (Judge \&Kammeyer-Mueller, 2012).

There is still a lack of effective focus on building an entrepreneurial mindset among agriculturalists. Investing in physical structures or providing training for better farm productivity is the usual response of governments to improve output in the agriculture sector. These efforts are important but wasteful if not coupled with a shift in thinking (Audinet\&Haralambous, 2005).

\section{OBJECTIVES OF THE STUDY}

The study described personal and business profile of the respondents. The study assessed the motivation factors of agripreneurs in terms of Job Characteristics, Critical Psychological State and Job Satisfaction. Further, this study determined the relationship between and among the profile of the respondents and motivation factors of agripreneurs.

\section{METHODOLOGY}

This study used descriptive-correlational design. Correlational research data may be used to determine the prevalence of variables and their relationships, as well as to forecast occurrences based on available data and information (Curtis et al., 2016). This study determined the relationships among sociodemographic and business profile of agripreneurs, motivation factors and challenges that were gathered through an online questionnaire. The researcher used purposive quota sampling in selecting the respondents. A quota of 62 agripreneurs in Nueva Ecija was established.

\section{RESULTS AND DISCUSSIONS}

Table 1. Personal Profile of the Respondents

\begin{tabular}{|c|c|c|}
\hline Age & Frequency & Percentage \\
\hline 30 and below & 1 & 1.61 \\
\hline $31-45$ & 9 & 14.52 \\
\hline $46-60$ & 48 & 77.42 \\
\hline \multirow[t]{2}{*}{ Above 60} & 4 & 6.45 \\
\hline & 62 & 100 \\
\hline Sex & Frequency & Percentage \\
\hline Male & 38 & 61.29 \\
\hline \multirow[t]{2}{*}{ Female } & 24 & 38.71 \\
\hline & 62 & 100 \\
\hline Civil Status & Frequency & Percentage \\
\hline Single & 2 & 3.23 \\
\hline Married & 54 & 87.10 \\
\hline Widowed/Separated & 6 & 9.68 \\
\hline Total & 62 & 100 \\
\hline $\begin{array}{c}\text { Highest Educational } \\
\text { Attainment }\end{array}$ & Frequency & Percentage \\
\hline High School & 14 & 22.58 \\
\hline College & 46 & 74.19 \\
\hline Graduate Studies & 2 & 3.23 \\
\hline Total & 62 & 100 \\
\hline
\end{tabular}

Table 1 presents the socio-demographic profile of the respondents in terms of their age, sex, civil status, and their highest educational attainment. Based on the data presented, the following results were drawn.

In terms of age, majority of respondents with a total of 48 $(77.42 \%)$ were 46 to 60 years old. In terms of sex, there were $38(61.29 \%)$ male respondents and there were 24 
(38.71\%) female respondents. In terms of civil status, most of the respondents with a total of $54(87.10 \%)$ were married. It can also be derived that there were $46(74.19 \%)$ respondents attained college level in terms of highest educational attainment.

Table 2. Business Profile of the Respondents

\begin{tabular}{|c|c|c|c|}
\hline Nature of Agribusiness & & Frequency & Percentage \\
\hline Crops & & 28 & 45.16 \\
\hline Fisheries & & 4 & 6.45 \\
\hline Poultry & & 20 & 32.26 \\
\hline \multirow[t]{2}{*}{ Other livestock } & & 10 & 16.13 \\
\hline & Total & 62 & 100 \\
\hline Number of years in Agribusiness & & Frequency & Percentage \\
\hline 5 years and below & & 12 & 19.35 \\
\hline 6 to 10 years & & 24 & 38.71 \\
\hline 11 to 15 years & & 12 & 19.35 \\
\hline \multirow[t]{2}{*}{ Above 15 years } & & 14 & 22.58 \\
\hline & Total & 62 & 100 \\
\hline Initial Investment for Agribusiness & & Frequency & Percentage \\
\hline P200,000 and below & & 14 & 22.58 \\
\hline $\mathrm{P} 200,001$ to $\mathrm{P} 400,000$ & & 25 & 40.32 \\
\hline $\mathrm{P} 400,001$ to $\mathrm{P} 600,000$ & & 6 & 9.68 \\
\hline \multirow[t]{2}{*}{ Above P600,000 } & & 17 & 27.42 \\
\hline & Total & 62 & 100 \\
\hline Source of Funding & & Frequency & Percentage \\
\hline Personal Savings & & 32 & 51.61 \\
\hline Loans & & 28 & 45.16 \\
\hline \multirow[t]{2}{*}{ Others } & & 2 & 3.23 \\
\hline & Total & 62 & 100 \\
\hline Average Monthly Profit & & Frequency & Percentage \\
\hline P100,000 and below & & 33 & 53.23 \\
\hline $\mathrm{P} 100,001$ to $\mathrm{P} 200,000$ & & 15 & 24.19 \\
\hline $\mathrm{P} 200,001$ to $\mathrm{P} 300,000$ & & 1 & 1.61 \\
\hline Above P300,000 & & 13 & 20.97 \\
\hline & Total & 62 & 100 \\
\hline
\end{tabular}

Table 2 presents the business profile of the respondents in terms of its nature of agribusiness, number of years in agribusiness, initial investment, source of funding and average monthly profit.

In terms of nature of agribusiness, there were $28(45.16 \%)$ respondents with crops as their agribusiness, while there were $20(32.26 \%)$ respondents with poultry as their agribusiness. Most of the respondents with a total of 24 $(38.71 \%)$ were already on $6^{\text {th }}$ to $10^{\text {th }}$ year in their agribusiness. A total of $25(40.32 \%)$ respondents initially invested P200,001-P400,000 to their respective agribusinesses. Most of the respondents with a total of 32 $(51.61 \%)$ funded their agribusiness through their personal savings. On the average, it can be derived that a total of 33 
$(53.23 \%)$ respondents were earning $\mathrm{P} 100,000$ and below monthly profit.

Table 3. Assessment on Motivation Factors of Agripreneurs in terms of Job Characteristics

\begin{tabular}{|c|c|c|}
\hline Statement/s & WM & $\begin{array}{c}\text { Verbal } \\
\text { Interpretation }\end{array}$ \\
\hline \multicolumn{3}{|l|}{ Skills Variety } \\
\hline 1. My job provides a lot of variety. & 3.27 & Strongly Agree \\
\hline 2. My job is very demanding and requires many different skills. & 2.61 & Agree \\
\hline 3. Many aspects of my job are simple and repetitive. & 2.44 & Disagree \\
\hline \multicolumn{3}{|l|}{ Task Identity } \\
\hline 4. I consider my job as holistic. & 3.29 & Strongly Agree \\
\hline $\begin{array}{l}\text { 5. I can not only partially but rather comprehensively influence the development of my } \\
\text { clients. }\end{array}$ & 2.65 & Agree \\
\hline 6. In my job, I do not have the ability to edit a complete a task from beginning to end. & 2.66 & Agree \\
\hline \multicolumn{3}{|l|}{ Task Significance } \\
\hline 7. My job is important to the life and well-being of the clients. & 3.26 & Strongly Agree \\
\hline 8. The quality of my job directly impacts my clients. & 3.03 & Agree \\
\hline 9. All in all my job is not very important and significant. & 2.45 & Disagree \\
\hline \multicolumn{3}{|l|}{ Autonomy } \\
\hline 10. I have full liberty in deciding how to structure my job. & 3.23 & Agree \\
\hline 11. I can independently plan and organize my job. & 2.95 & Agree \\
\hline $\begin{array}{l}\text { 12. I have become so hampered by guidelines and specifications that I can hardly bring } \\
\text { original ideas into my job. }\end{array}$ & 2.53 & Agree \\
\hline \multicolumn{3}{|l|}{ Feedback } \\
\hline 13. In carrying out my job activities, it is easy for me to say, how well I perform my job. & 2.87 & Agree \\
\hline 14. My job provides little feedback on the actual quality of my work. & 2.73 & Agree \\
\hline Average Weighted Mean & 2.86 & Agree \\
\hline
\end{tabular}

\section{Legend}

$3.25-4.00$

\section{Verbal Interpretation}

$2.50-3.24$

Strongly Agree

$1.75-2.49$

Agree

$1.00-1.74$
Table 3 presents the assessment on motivation factors of agripreneurs in Nueva Ecija in terms of job characteristics. Job characteristics can be divided into five aspects namely, skills variety, task identity, task significance, autonomy, and feedback.

The result shows that agripreneur-respondents had an average mean of 2.86 in overall job characteristics as a motivation factor which has a verbal interpretation of "Agree".

To highlight the statements with highest means for each aspect are as follows: Skills Variety - Item 1 "My job provides a lot of variety." (Mean = 3.27; Strongly Agree); Task Identity - Item 4 “.” (Mean = 3.29; Strongly Agree); Task Significance - Item 7 "My job is important to 
the life and well-being of the clients." (Mean = 3.26; Strongly Agree), Autonomy - Item 10 "I have full liberty in deciding how to structure my job." (Mean = 3.23, Agree); and Feedback - Item 13 "In carrying out my job activities, it is easy for me to say, how well I perform my job." (Mean $=2.87$, Agree).

Agripreneurs in Nueva Ecija are responsible for more than just management and business management. They were also hands-on in their business, performing tasks that an owner would not normally perform because the majority of them did not have staff (farmers) or a large number of staff to assist them. Growing and harvesting crops, raising poultry, and preparing them for market are all jobs for agripreneurs.

The findings indicate that agripreneurs in Nueva Ecija are motivated by job characteristics. They understand that their job requires a wide range of skills because it is not simple or repetitive. In their business tasks, they identify their job holistically by influencing the development of their customers comprehensively, which entails the ability to complete tasks as soon as they begin it. They find meaning and significance in their job, which contributes to how they impact the well-being of their clients. Agripreneurs are self-sufficient in their job execution as well as in planning, organizing, and managing the structure of their job.

As a result, they can contribute their own ideas to their job. They are also motivated when they receive feedback from their customers, whether it is positive or negative. According to Meyerding (2018), insights into the attractiveness of job characteristics as well as reliable knowledge about the characteristics of applicants available to employers contribute to a more open situation in which better-informed decisions can be taken by candidates and employers, resulting in improved job satisfaction, success and longevity of careers. Further of Wolf \&Qenani-Petrala (2004) stated that the influence of job characteristics was taken into account by including variables such as form of occupation, area of employment, position in the business and starting salary.

Table 4. Assessment on Motivation Factors of Agripreneurs in terms of Critical Psychological State

\begin{tabular}{|c|c|c|}
\hline Statement/s & WM & Verbal Interpretation \\
\hline \multicolumn{3}{|l|}{ Experience Meaningfulness } \\
\hline 1. The work I am doing means a lot to me. & 3.26 & Strongly Agree \\
\hline 2. I consider my work to be very important and useful. & 3.34 & Strongly Agree \\
\hline 3. Many of my tasks seem useless and insignificant. & 2.39 & Disagree \\
\hline \multicolumn{3}{|l|}{ Experienced Responsibility } \\
\hline 4. I feel a great deal of personal responsibility for the work I am doing. & 3.16 & Agree \\
\hline 5. I am clearly responsible for whether my clients learn something or not. & 2.77 & Agree \\
\hline $\begin{array}{l}\text { 6. It is often hard for me to worry much about whether my work is done } \\
\text { well. }\end{array}$ & 2.65 & Agree \\
\hline \multicolumn{3}{|l|}{ Knowledge of Results of the Work Activities } \\
\hline 7. I usually know if I have done my job satisfactorily. & 3.13 & Agree \\
\hline 8. I find it often easy to predict whether I have done my job well or poorly. & 2.71 & Agree \\
\hline 9. I can hardly determine whether I am doing my job well or not. & 2.40 & Disagree \\
\hline Average Weighted Mean & 2.87 & Agree \\
\hline
\end{tabular}

\section{Legend Verbal Interpretation}

$3.25-4.00 \quad$ Strongly Agree

$2.50-3.24 \quad$ Agree

$1.75-2.49 \quad$ Disagree

$1.00-1.74 \quad$ Strongly Disagree

Table 4 presents the assessment on motivation factors of agripreneurs in Nueva Ecija in terms of critical psychological state. Critical psychological states are divided into three aspects namely experience 
meaningfulness, experienced responsibility, and Knowledge of results of the work activities. The result shows that agripreneur-respondents had an average mean of 2.87 in critical psychological state as a motivation factor which has a verbal interpretation of "Agree".

To highlight the statements with highest means for each aspect are as follows: Experience Meaningfulness - Item 2"I consider my work to be very important and useful." (Mean = 3.34; Strongly Agree); Experienced Responsibility - Item 4 "I feel a great deal of personal responsibility for the work I am doing." (Mean = 3.16; Agree); and Knowledge of Results of the Work Activities Item 7"I usually know if I have done my job satisfactorily.” (Mean = 3.13; Agree).

These findings imply that agripreneurs in Nueva Ecija believe their work has meaning for them because of its importance and usefulness, which means a lot to them as agripreneurs. They also gain personal responsibility for the outcomes of their work by addressing their personal responsibilities and acknowledging how their work was completed. Furthermore, agripreneurs understand the success of their work because it is often easy to predict whether they have done their job well or poorly. This confirms the result of Ulianchenko et al. (2019) as labor motivation is an employee's attitude to the work carried out, which is based on the priorities of wants, desires and motivation. And, on the other hand, the company's management should conduct those actions directed at the staff's efforts to fully achieve the organization's goals. However, Bessell et al. (2002) found that there should be thinking about incentives and recognition, it is also a good idea to recognize career growth and where people are in their careers. Pay rewards, for example, may appeal to young employees, opportunities for professional advancement may interest mid-career associates, and being part of policy and strategic planning may interest longterm associates.

Table 5. Assessment on Motivation Factors of Agripreneurs in terms of Job Satisfaction

\begin{tabular}{|c|c|c|}
\hline Statement/s & WM & Verbal Interpretation \\
\hline 1. All in all I am very satisfied with my job. & 3.27 & Strongly Agree \\
\hline 2. I often think about changing jobs. & 2.69 & Agree \\
\hline 3. In general, I am satisfied with the nature of my job. & 3.08 & Agree \\
\hline $\begin{array}{l}\text { 4. I am very satisfied with my prospects with the current institution. I am very } \\
\text { satisfied with the opportunities of my current situation. }\end{array}$ & 2.90 & Agree \\
\hline $\begin{array}{l}\text { 5. I am very satisfied with the respect and fair treatment by management. I am very } \\
\text { satisfied with the respect and fair treatment we have in this business. }\end{array}$ & 2.94 & Agree \\
\hline 6. I am very satisfied with the income of my business & 2.85 & Agree \\
\hline 7. I am very satisfied with the extent of support that I receive for my business. & 3.10 & Agree \\
\hline $\begin{array}{l}\text { 8. I am very satisfied with the extent to which I can reward myself and family } \\
\text { based on the performance of my business. }\end{array}$ & 2.94 & Agree \\
\hline 9. I am very satisfied with the quality of my management of my business. & 2.89 & Agree \\
\hline $\begin{array}{l}\text { 10. I am very satisfied with the ability to develop myself personally through my } \\
\text { job. }\end{array}$ & 2.85 & Agree \\
\hline 11. I am very satisfied with the feeling of achieving something valuable by my job & 2.92 & Agree \\
\hline 12. I am very satisfied with the security of my job. & 2.89 & Agree \\
\hline $\begin{array}{l}\text { 13. I am very satisfied with the degree of independence regarding thinking and } \\
\text { acting at my job. }\end{array}$ & 2.97 & Agree \\
\hline 14. I am very satisfied with the extent to which my job challenges me personally & 3.23 & Agree \\
\hline Average Weighted Mean & 2.97 & Agree \\
\hline
\end{tabular}



2.50 - $3.24 \quad$ Agree
$1.75-2.49 \quad$ Disagree
1.00 - $1.74 \quad$ Strongly Disagree

Table 5 presents the assessment on motivation factors of agripreneurs in Nueva Ecija in terms of job satisfaction.

The result shows that agripreneur-respondents had an average mean of 2.97 in job satisfaction as a motivation factor which has a verbal interpretation of "Agree".

The statements with highest means are as follows: Item 1 "All in all I am very satisfied with my job." (Mean = 3.27; Strongly Agree), Item 14 "I am very satisfied with the extent to which my job challenges me personally" (Mean $=3.23$; Agree), Item 7 "I am very satisfied with the extent of support I receive for my business. " (Mean $=3.10$; Agree), and Item 3 "In general, I am satisfied with the nature of my job." (Mean = 3.08; Agree).

The findings indicate that agripreneurs in Nueva Ecija, in general, are satisfied with their jobs, whether they like the job itself or specific aspects or facets of it. According to their responses, agripreneurs are satisfied even when they face personal work challenges. This can be attributed to the respect and fair treatment they they have in their business. Another factor influencing agripreneurs' job satisfaction is their level of independence in terms of thinking and acting at their job. Moreover, because they enjoy their job as agripreneurs, they regard it as valuable and significant. Thus, Hoque et al. (2016) found that a well-built organizational culture, empowerment and participatory method acknowledgement are established by the specific business. Recognition and career policies and congenial business policies help to meet corporate goals very efficiently and effectively. Further, this confirms the study of Marri et al. (2012) that employees in agriculture sector institutions have shown a clear commitment to a cooperative and team-oriented environment; Employees' efforts should be compensated reciprocally by the company in order to ensure that they have an equitable chance of advancement in life and equal opportunity for professional growth and career progression.

Table 6. Correlation between Profile of the respondents and Motivation Factors

\begin{tabular}{|c|c|c|c|c|c|c|c|c|c|}
\hline & Age & Sex & $\begin{array}{c}\text { Highest } \\
\text { Educational } \\
\text { Attainment }\end{array}$ & $\begin{array}{l}\text { Number of } \\
\text { years in the } \\
\text { Agribusiness }\end{array}$ & $\begin{array}{c}\text { Initial } \\
\text { Investment } \\
\text { for } \\
\text { Agribusiness }\end{array}$ & $\begin{array}{l}\text { Average } \\
\text { Monthly } \\
\text { Profit }\end{array}$ & $\begin{array}{c}\mathrm{JC} \\
\text { Mean }\end{array}$ & $\begin{array}{l}\text { CPS } \\
\text { Mean }\end{array}$ & $\begin{array}{c}\text { JS } \\
\text { Mean }\end{array}$ \\
\hline Age & 1 & & & & & & & & \\
\hline Sex & .085 & 1 & & & & & & & \\
\hline $\begin{array}{r}\text { Highest } \\
\text { Educational } \\
\text { Attainment }\end{array}$ & -.160 & $-.307^{*}$ & 1 & & & & & & \\
\hline $\begin{array}{r}\text { Number of } \\
\text { years in the } \\
\text { Agribusiness }\end{array}$ & $.347^{* *}$ & -.197 & .062 & 1 & & & & & \\
\hline $\begin{array}{r}\text { Initial } \\
\text { Investment } \\
\text { for } \\
\text { Agribusiness }\end{array}$ & -.076 & -.179 & .129 & $-.481^{* *}$ & 1 & & & & \\
\hline $\begin{array}{r}\text { Average } \\
\text { Monthly } \\
\text { Profit }\end{array}$ & .137 & $-.278^{*}$ & $.442^{* *}$ & -.009 & $.620^{* *}$ & 1 & & & \\
\hline
\end{tabular}




\begin{tabular}{r|ccccccccc} 
JC & -.049 & -.046 & -.096 & .179 & -.197 & -.052 & 1 & & \\
Mean & & & & & & & & & \\
CPS & 106 & -.182 & $.335^{* *}$ & $.354^{* *}$ & -.091 & $.257^{*}$ & $326^{* *}$ & 1 \\
Mean & .18 & & & & & & \\
JS & $.282^{*}$ & -.239 & .098 & $.284^{*}$ & .156 & $.480^{* *}$ & $.305^{*}$ & $378^{* *}$ & 1 \\
Mean & & & & & & & &
\end{tabular}

Table 6 shows the results significant relationships of the personal profile of the agripreneur-respondents and their motivation factors using Pearson $r$ correlation coefficient. The profile of the agripreneur-respondents include age, sex, highest educational attainment, number of years in the agribusiness, initial investment for agribusiness,and average monthly profit. The motivation factors include job characteristics, critical psychological state, and job satisfaction.

Results show that age $(\mathrm{r}=.282, \mathrm{p}<.05)$, the number of years in agribusiness $(\mathrm{r}=.284, \mathrm{p}<.05)$ and the average monthly profit $(\mathrm{r}=.326, \mathrm{p}<.01)$ have weak positive correlations to job. This indicates that as the age of the agripreneurs go higher, and/or they have more number of years in the agribusiness, and/or there is an increase on their average monthly profit, the more they are motivated. They also have more contentment or satisfaction with their job, whether they like the job of individual aspects or facets of jobs. Further, results show that the highest educational attainment $(\mathrm{r}=.335, \mathrm{p}<.01)$, the number of years in agribusiness $(\mathrm{r}=.354, \mathrm{p}<.01)$, and the average monthly profit $(\mathrm{r}=.326, \mathrm{p}<.01)$ have weak positive correlations to with the motivation factor which is critical psychological state. This implies that the higher the educational attainment, and / or higher number of years in the agribusiness, and/or higher average month profit of the agripreneurs, the more they feel the value and meaning of their job and the more they know how successful their work has been. It was also found out that the three aspects of motivation factors such job characteristics, critical psychological states, and job satisfaction have weak intercorrelations with one another. This means that when the score of motivation factor increases the score of other motivation factors also increases. However, the profile of the agripreneur-respondents was not found to be correlated to the job characteristics as a motivating factor.

\section{CONCLUSIONS AND RECOMMENDATIONS}

Based on the results of the study, the following conclusions are made:The majority of Nueva Ecija'sagripreneurs were all middle aged adults. Because there were nearly equal numbers of male and female agripreneurs in Nueva Ecija, the job of agripreneur was not sex-determined. Majority of them were already married and attained college level in terms of highest educational attainment.Crops were the most of the products of agripreneurs. They have been agripreneurs for about a decade. They funded their initial investment for their respective agribusinesses through their personal savings. Most of the agripreneurs in Nueva Ecija are earning below their initial investment as reflected on their monthly profit.

Agripreneurs in Nueva Ecija are motivated by job characteristics where they understood that their job requires a wide range of skills because it is not simple or repetitive. They believed their job has meaning for them because of its importance and usefulness, which meant a lot to them as agripreneurs. This contributed to how they impact the well-being of their clients. Thus, agripreneurswere satisfied with their jobs when they face personal work challenges. Then, the main motivating factor for agripreneurs was found to be job satisfaction.

Profile of the agripreneurs have positive correlations to motivating factors such critical psychological state and job satisfaction but only limited to age, highest educational attainment, number of years in the agribusiness, and average monthly income. Further, job characteristics as a motivating factor were found no significant relationships with the profile of the agripreneurs.

Future researchers may explore more on the demographic of the agripreneurs. They may include courses of the agripreneurs if these were related to their job, trainings, and seminars attended in relation to agribusiness. Studies on agripreneurs should not only focus on related to crops, poultry, and aquaculture. Agripreneurs related to innovations such as farm machineries can be included. Business profile should also include partnerships with other entrepreneurs and business agencies.

\section{REFERENCES}

[1] Bairwa, S. L., Lakra, K., Kushwaha, S., Meena, L. K., \& Kumar, P. (2014). Agripreneurship development as a tool to upliftment of agriculture. International 
Journal of Scientific and Research Publications, 4(3), $1-4$.

[2] Bessell, I., Dicks, B., Wysocki, A., \&Kepner, K. (2002). Understanding motivation: an effective tool for managers. Florida: University of Florida, 1-4

[3] Hoque, F., Rabbany, G., Anny, S. A., \&Akhter, A. (2016). Level of job satisfaction in agribusiness sector in Bangladesh: An application of Hertzberg two factors motivation theory. International Journal of Economics, Commerce and Management, 4(6), 419445.

[4] Judge, T. A., \&Kammeyer-Mueller, J. D. (2012).Job attitudes. Annual review of psychology, 63, 341-367.

[5] Marri, M. Y. K., Sadozai, A. M., Zaman, H. M. F., \&Ramay, M. I. (2012). The impact of Islamic work ethics on job satisfaction and organizational commitment: a study of agriculture sector of Pakistan. International Journal of Business and Behavioral Sciences, 2(12), 32-45.

[6] Meyerding, S. G. (2018). Job preferences of agricultural students in Germany-A choice-based conjoint analysis for both genders. International Food and Agribusiness Management Review, 21(10302018-1788), 219-236..

[7] Philippine Statistics Authority (2004).A Review of the Agriculture Sector in Central Luzon.released on November 8, 2004 with Reference No. 124, retrieved from https://psa.gov.ph/content/review-agriculturesector-central-luzon on June 3, 2021.

[8] Qenani-Petrela, E., \& Wolf, M. M. (2007). Differential Earnings of the Agricultural Graduates: New Evidence from the Agribusiness Industry. International Food and Agribusiness Management Review, 10(1030-2016-82447), 49-66.

[9] Santiago, A., \& Roxas, F. (2015). Reviving farming interest in the Philippines through agricultural entrepreneurship education. Journal of Agriculture, Food Systems, and Community Development, 5(4), 15-27. http://dx.doi.org/10.5304/jafscd.2015.054.016

[10] Ulianchenko, O. V., Sheludko, R. M., Ponomarova, M. S., \&Sheludko, L. V. (2019).Motivation management as the key factor of financial and economic growth of small agribusiness enterprises. Financial and credit activity: problems of theory and practice, 4(31), 239-248.

[11] Yusoff, A. (2017). Antecedents of agropreneurship intention and behavior among Malaysia Gen Y: A longitudinal approach (Doctoral Dissertation). Retrieved from https://doi.org/10.13140/RG.2.2.10970.85448 